\title{
1844-1845 Tarihli Temettuât Defterine Göre Hüdavendigâr Eyâleti Gölpazarı Kazası Kasımlar Köyü'nün Sosyal ve Ekonomik Durumu
}

\author{
Ali Karahan*
}

(ORCID ID: 0000-0002-9147-4599)

\author{
Makale Gönderim Tarihi \\ 28.01.2020
}

Makale Kabul Tarihi

20.02.2020

\section{Özet}

Bu çalışmada, 1844-1845 tarihli ve 8044 numaralı Temettuât Defterindeki verilere dayanılarak Kasımlar Köyü'nün sosyal, ekonomik ve demografik durumu hakkında bazı değerlendirmeler yapıldı. Osmanlı Devleti'nin 18441845'teki idarî taksimatına göre Hüdavendigâr Eyâleti dâhilindeki Gölpazarı Kazası'na bağıı bir yerleşim yeri olan Kasımlar Köyü'nde 93 adet vergi mükellefi hane ikamet etmekteydi ve bunların içerisinde gayrimüslim herhangi bir kişi bulunmamaktaydı. Bu dönemde Kasımlar Köyü'ndeki haneler tarım ve hayvancılıktan elde ettikleri gelirlerle geçimlerini sağlıyorlardı. Zirâat yapmaya elverişli ekili arazilerde buğday, arpa, pamuk, burçak, üzüm gibi meyve ve tahıl ürünleri üretiliyordu. Ekilebilir arazilerin önemli bir bölümünde ise ipek böcekçiliği yapılıyordu. Ayrıca et, süt, güç ve diğer özelliklerinden istifade etmek için büyükbaş, küçükbaş, yük ve binek hayvanları yetiştiriliyordu.

Anahtar Kelimeler: Kasımlar Köyü, Gölpazarı Kazası, Temettûat, Hüdavendigâr Eyâleti

\section{Abstract}

The Social and Economic Status of Kasımlar Village of Gölpazarı Town of Hüdavendigâr State Based On Temettuât Book Dated 1844-1845

In this study, some evaluations were made about the social, economic, and demographic situation of Kasımlar village based on data in the Temettuât book of numbered 8044 and dated 1844-1845. According to the administrative division of the Ottoman State in 1844-1845, 93 taxpayers were living in the

\footnotetext{
* Dr. Öğr. Üyesi, Bilecik Şeyh Edebali Üniversitesi, Fen-Edebiyat Fakültesi, Tarih Bölümü, alikarahan46@gmail.com.
}

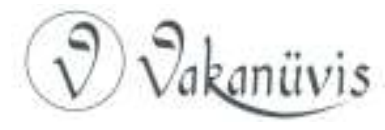


village of Kasımlar, which is a settlement of the Gölpazarı town within Hüdavendigâr province and there is no non-Muslim person among them. In this period, households in Kasımlar village obtained their living by earning income from agriculture and animal husbandry. Fruit and cereal products such as wheat, barley, cotton, vetch, grape were produced on arable lands suitable for agriculture. Silk beetle was carried out on a significant part of the arable lands. In addition, cattle, ovine, pack and mount animals were raised to take advantage of meat, milk, power and other features.

Keywords: Kasımlar Village, Gölpazarı Town, Temettuât, Hüdavendigâr Province

\section{Giriş}

Osmanlı Devleti, Tanzimat Fermanı́nın ilanıyla başlayan süreçte yapılan reformlarla hemen her alanda değişim ve dönüşüm yaşadı. Bu dönemde malî yapıdaki aksaklıkların ve ahali nezdinde adaletsizliklerin başlıca nedenlerinden biri olarak görülen vergilendirme usulüyle ilgili de önemli düzenlemelerin hayata geçirilmesi kararlaştırıldı. Uygulanacak bu yeni düzenlemelerle birlikte daha evvel ahaliden toplanan örfí vergiler kaldırılarak yerine senelik kazanç üzerinden hesaplanan "temettü" veya diğer adıyla "an cemâatin" ${ }^{1}$ vergisi ikame olunacaktı. Bu düşünce doğrultusunda 1840 ve 1844-1845'te tahrirler yapılarak hane reislerinin adı, şöhreti, arazileri, hayvanları; tüccar ile esnafın da senelik gelirleri hakkında verilerin kaydedildiği "Temettuât Defterleri" tanzîm edildi. ${ }^{2}$ Osmanlı Arşivi'nde Kamil Kepeci ve Maliyeden Müdevver

\footnotetext{
1 Tanzimat döneminde mükelleflerin senelik kazançları üzerinden hesaplanarak daha evvel toplanan örfî vergilerin yerine tek tip olarak ikame edilen "temettü" veya "an cemâatin" vergisinin sonraki senelerde geçirdiği safahat hakkında bkz. M. Zeki Pakalın, "Temettü' Vergisi", Osmanlı Tarih Deyimleri ve Terimleri Sözlüğü, III, Millî Eğitim Basımevi, i̇stanbul 1983, s. 453-455.

2 Abdurrahman Vefik Sayın, Tekâlif Kavaidi (Osmanlı Vergi Sistemi), Maliye Bakanlığı Araştırma, Planlama ve Koordinasyon Kurulu Başkanlığı Yayınları, II, Ankara 1999, s. 441442; Tevfik Güran, "19. Yüzyıl Temettüat Tahrirleri", Osmanlı Devleti'nde Bilgi ve istatistik, Der. Halil İnalcık-Şevket Pamuk, Devlet İstatistik Enstitüsü Yayınları, Ankara 2000, s. 76; Mübahat S. Kütükoğlu, “Osmanlı Sosyal ve İktisâdî Tarihi Kaynaklarından Temettü Defterleri”, Belleten, LIX/238, Ankara 1999, s. 395-396; Said Öztürk, "Temettuat Tahrirleri", Akademik Araştırmalar Dergisi, 4-5, İstanbul 2000, s. 545-547; Nuri Adıyeke, "Temettuat Sayımları ve Bu Sayımları Düzenleyen Nizamname Örnekleri",
}

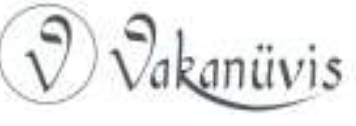


Defterler serisi içerisinde yer alan Temettuât Defterleri, 1988 senesinde "ML.VRD.TMT.d (Maliye Nezareti Varidat Muhasebesi Temettuât Defterleri)" koduyla analitik envanter sistemine göre tasnif edildi ve 17.747 adeti kataloglanarak araştırmacıların hizmetine sunuldu. Defterlerin büyük kısmı 1844-1845'te yapılan tahrirlere aittir. Ayrıca, az sayıda olmakla birlikte 1840 'ta gerçekleştirilen ilk tahrirlere ait defterler de mevcuttur. ${ }^{3}$

Bu çalışmada, günümüzde Bilecik Vilâyeti Gölpazarı Kazası'na bağlı Kasımlar Köyü'nün sosyal, ekonomik ve demografik durumu hakkında 1844-1845'te yapılan tahrirlerle ilgili verilerden istifade edilerek bazı değerlendirmeler yapılacaktır. Kasımlar Köyü, coğrafya bakımından Bilecik'in doğusunda; Gölpazarı'nın güneyinde ve Söğüt'ün kuzeyinde konumlanmıştır. Mesafe olarak ise Bilecik'e 33, Gölpazarı'na 12 ve Söğüt'e $42 \mathrm{~km}$ uzaklıktadır. 1844-1845 tahrirleri esnasında da yine Hüdavendigâr Eyâleti dâhilindeki Gölpazarı Kazası'na ${ }^{4}$ tâbi bir yerleşim yeri olan Kasımlar Köyü'nün müstakil bir adet Temettuât Defteri bulunmaktadır. Osmanlı Arşivi'nde 8044 numarada kayıtlı bu defter, $18 \times 50 \mathrm{~cm}$ ebadındadır ve yazılı kısmı 49 sayfadır. Köyde ikamet eden hane reisleri ile ilgili bilgilerin kaydı defterin ikinci sayfasından itibaren başlamaktadır. Her sayfada ortalama 4 hane reisine ait veriler yer almaktadır. Defter "Hüdâvendigâr Eyâleti'ne mülhak kazâlardan

Ankara Üniversitesi Osmanlı Tarihi Araştırma ve Uygulama Merkezi Dergisi, 11, Ankara 2000, s. 779-780.

3 Osmanlı Devleti'nin o dönemki şartları dolayısıyla ülkenin tamamında tahrirler gerçekleştirilememiştir. Bu münasebetle 1988'de tasnif edilerek kataloglanan 17.747 adet Temettuât Defteri Ankara, Aydın, Bolu, Cezâyir-i Bahr-ı Sefîd, Edirne, Erzurum, Hüdavendigâr, Konya, Niş, Rumeli, Selânik, Silistre, Sivas, Üsküb ve Vidin eyâletlerine aittir. Ayrıntılar için bkz. Başbakanlık Osmanlı Arşivi Rehberi, Haz. Yusuf ìhsan Genç vd., Başbakanlık Devlet Arşivleri Genel Müdürlüğü Osmanlı Arşivi Daire Başkanlığı Yayınları, Ankara 2010, s. 248-249.

${ }^{4}$ Gölpazarı'nın idarî durumuna dair resmî arşiv kayıtları XV. yüzyılın sonlarına dek gitmektedir. Bu dönemde Gölpazarı'nın Hüdavendigâr Sancağı'na bağlı 28 kadar nahiyeden biri olduğu görülmektedir (Feridun Emecen, "Hudâvendigâr", Türkiye Diyanet Vakfı İsâm Ansiklopedisi, XVIII, s. 285). Osmanlı Devleti'nde vergi mükellefleri ve bunların mal varlıklarına dair verilerin kaydedildiği 1487, 1530 ve 1575 senelerine ait Hüdavendigâr Sancağı Tahrir Defterlerine göre Gölpazarı nahiyesinin kırsaldaki köyleriyle birlikte toplam nüfusu ise sırasıyla 1.060, 1.240 ve 2.493 kişidir (Vedat Turğut, Bilecik Bölgesi Örneğinde 16. Yüzyılda Vakıflar ve Şehirleşme, Sakarya Üniversitesi Sosyal Bilimler Enstitüsü Basılmamış Doktora Tezi, Sakarya 2011, s. 157, 158, 212-230).

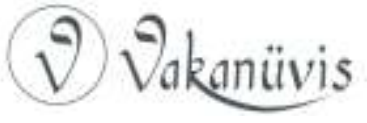


Gölpazarı Kazâsı kurâlarından Kasımlar karyesinde mukim ahâlinin emlâk ve arâzî ve temettu'âtlarını mübeyyin defteridir" ibaresiyle başlamaktadır ve hanelerin 1844 'te devlete ödedikleri vergi-yi mahsusalar ile tahrirler neticesinde tespit edilen senelik kazançlarının genel toplamlarıyla bitmektedir. Ayrıca, defterin yazılı son sayfasında Kasımlar Köyü'nün birinci ve ikinci muhtarı ile imamının mühürleri de bulunmaktadır. ${ }^{5}$

\section{1- Nüfusu ve Hane Reislerinin Meslekî Yapılanması}

\section{Şahıs Adları ve Sıfatları}

1844-1845 temettuât tahrirlerinin yapıldığı esnada Kasımlar Köyü'nde toplam 93 adet hane bulunmaktadır. ${ }^{6}$ Demografi çalışmalarında hanelerdeki ${ }^{7}$ kişiler için genel kabul gören 5 rakamı ${ }^{8}$ ile 93 çarpıldığında Kasımlar Köyü'nün 465 civarında nüfusa sahip olduğu ortaya çıkmaktadır. Bu nüfusun içerisinde herhangi bir gayrimüslime tesadüf edilmemiştir. Diğer taraftan, aynı dönemde Hüdavendigâr Eyâleti'nin Bilecik Kazası'ndaki 27 adet köyün takribî nüfusu 11.450

${ }^{5}$ Kasımlar Köyü'ne ait Temettuât Defteri'nin yazılı birinci ve son sayfası için bkz. Başbakanlık Osmanlı Arşivi (BOA), Maliye Varidat Muhasebesi Temettuât Defterleri (ML. VRD. TMT. d.), nr. 8044, s. 2, 50.

${ }^{6}$ Defterde vergi mükelleflerinin sayısı 97 kişi olarak kaydedilmiştir. Bunun nedeni 1, 61 ve 88 numaralı hanelerde fazladan 4 adet vergi mükellefinin ikamet etmesidir. Çalışmada hane reislerinin dışında vergiye tâbi bu 4 kişi, şahıs adları ve sıfatları ile mesleki yapılanmanın izah edildiği kısımlarda bireysel, diğer yerlerde ise ait oldukları hane içerisinde değerlendirilmişlerdir.

7 Osmanlı Devleti'nde XV-XVI. yüzyıllarda hane, vergiye tâbi bir birim olarak değerlendirilmekteydi ve çekirdek veya büyük aileye karşılık gelmemekteydi. Ancak bu durumun XIX. yüzyılda değiştiği ve hanenin vergi yükümlüsü bir birimden ziyade sosyolojik olarak çekirdek ya da büyük aileyi ifade ettiği belirtilmektedir (Kemal H. Karpat, Osmanlı Nüfusu 1830-1914, Timaş Yayınları, İstanbul 2010, s. 44-45).

8 Demografi çalışmalarında hanelerdeki kişi sayısını hesaplamak için çoğunlukla kullanılan 5 rakamı Ömer Lütfi Barkan'a aittir ("Tarihî Demografi Araştırmaları ve Osmanlı Tarihi", Türkiyat Mecmuası, X, İstanbul 1953, s. 12). Buna mukabil Nejat Göyünç hanelerdeki kişi sayısını hesaplamada 4,17 rakamının kullanılması gerektiği kanaatindedir ("Hâne Deyimi Hakkında", İstanbul Üniversitesi Edebiyat Fakültesi Tarih Dergisi, 32, İstanbul 1979, s. 345). Göyünç'ün hane kişi sayısı için verdiği 4,17 rakamı ile 93 çarpıldığında Kasımlar Köyü’nün nüfusu 387 civarında çıkmaktadır. İki katsayıyla hesaplanıp elde edilen sonuçlar birbirinden çıkarıldığında ise nüfus farkının 78 olduğu görülmektedir.

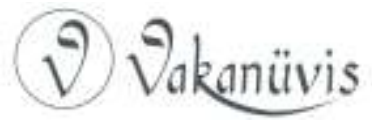


kişidir. ${ }^{9}$ Köylerdeki mevcut 11.450 kişi 27 'ye bölündüğünde ortalama nüfus 424 olmaktadır. Hüdavendigâr Eyâleti'nin bir başka kazası Söğüt'teki 15 adet köyde ise nüfusun 6.030 civarında olduğu görülmektedir. ${ }^{10} 6.030$ rakamı $15^{\prime}$ e bölündüğünde de ortalama nüfus 402 olarak elde edilmektedir. Bu durumda Kasımlar'daki 465 kişilik nüfusun Bilecik ve Söğüt kırsalındaki köylerin ortalamalarından daha fazla olduğunu belirtmek mümkündür.

Temettuât Defterlerinde vergi mükellefi kişilerin adları ve ikamet ettikleri hanelerin numaraları açıkça kaydedilmiştir. Bu çerçevede Kasımlar Köyü'ne ait defterde hane reisleri genellikle "Sarıoğlan oğlu Mehmed bin Hüseyin", "Serdar oğlu Mehmed bin Osman", "Ömer oğlu ibrahim bin Halil" şeklinde aile ve baba adlarıla birlikte verilmişlerdir. Hane reislerinden bazılarının da sosyal statüleri, lakapları ve fizikî açıdan öne çıkan özellikleriyle tanımlandıkları görülmektedir. Mesela "el-Hac Emin", "Hacı Abdullah", "Molla Ali", "Molla Osman", "Kara Mustafa" ve "Eğriboyun" gibi adları bu gruba dâhil etmek mümkündür. Defterdeki hane reislerinin adları ile ilgili tanımlayıcı bilgiler üzerinden çıkarılabilecek bir başka husus ise Kasımlar Köyü'nde ikamet eden vergi mükelleflerinin çoğunluğunun birbirleriyle akrabalık ilişkisine sahip olduklarıdır. Nitekim aile adlarından bazıları bir kısım vergi mükellefiyle birlikte kaydedilmiştir. Bu duruma örnek vermek gerekirse 78/1, 79/1, $80 / 1,88 / 1$ ve $88 / 3$ numaralı hanelerde kayıtlı vergi mükelleflerinden "Aygır oğlu Kara Mustafa bin Latif", "Aygır oğlu Muhammed bin Latif", "Aygır oğlu Molla Ali bin Latif", "Aygır oğlu Yusuf bin Latif" ile "Aygır oğlu Hasan bin Latif"in kardeş; 87/1, 89/1 ve 41/1 numaralardaki "Hasancık oğlu Hacı Abdullah bin Hasan", "Hasancık oğlu Halil bin Hacı Abdullah" ile "Hasancık oğlu Ali bin Halil" in üç kuşak sırasıyla dede, oğul ve torun; 4/1, 20/1 ve 21/1 numaralardaki "Çil Hasan oğlu ilyas bin Hasan", "Çil Hasan oğlu Mustafa bin ibrahim" ile "Çil Hasan oğlu Hüseyin bin Ali"nin de aynı aileye mensup oldukları anlaşılmaktadır. Köydeki vergi mükelleflerinin adları içerisinde en sık rastlanılanları ise 10 'ar adetle Ali ve İbrahim'dir. Bunları sırasıyla Hüseyin, Hasan,

\footnotetext{
${ }^{9}$ Said Öztürk, Tanzimat Döneminde Bir Anadolu Şehri Bilecik, Kitabevi Yayınları, İstanbul 1996, s. 52-53.

10 İsmail Gökçe, 1844-45 Yılı Temettuat Sayımlarına Göre Söğüt ve Kırsalının Sosyal ve Ekonomik Yapısı, Eskişehir Osmangazi Üniversitesi Sosyal Bilimler Enstitüsü Basılmamış Yüksek Lisans Tezi, Eskişehir 2017, s. 12-13.
}

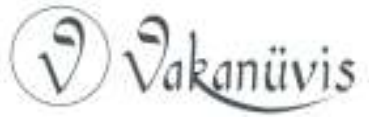


Mustafa, Mehmed ve Halil takip etmektedir. En az rastlanılan adlar da Yusuf, Abdullah, Musa, Veli, Süleyman ve Eyüb'dür. Köydeki vergi mükelleflerinin adları incelendiğinde genellikle dinî kökenli oldukları görülmektedir. ${ }^{11}$

Tablo 1. Kasımlar Köyü’nde İkamet Eden Hane Reisleri ve Ailelerinin Adları

\begin{tabular}{|c|c|c|}
\hline $\begin{array}{c}\text { Hacı oğlu Hacı Hasan } \\
\text { bin Hacı Abdullah }\end{array}$ & $\begin{array}{c}\text { Hacı oğlu Ahmed bin } \\
\text { Hacı Hasan }\end{array}$ & $\begin{array}{l}\text { Himmet oğlu } \\
\text { Mustafa bin Ali }\end{array}$ \\
\hline $\begin{array}{c}\text { Koca Ali oğlu Ali bin } \\
\text { Mehmed }\end{array}$ & $\begin{array}{c}\text { Çil Hasan oğlu ilyas } \\
\text { bin Hasan }\end{array}$ & $\begin{array}{c}\text { Pirli oğlu Hasan bin } \\
\text { Halil }\end{array}$ \\
\hline $\begin{array}{l}\text { Kethüdanın İsmail } \\
\text { bin Ömer }\end{array}$ & $\begin{array}{l}\text { Hasancık oğlu Hacı } \\
\text { Ahmed bin Hasan }\end{array}$ & $\begin{array}{l}\text { Sarıoğlan oğlu } \\
\text { Mustafa bin Ali }\end{array}$ \\
\hline Ali oğlu İsmail bin Ali & $\begin{array}{l}\text { Himmet oğlu } \\
\text { Ibrahim bin Emin }\end{array}$ & $\begin{array}{c}\text { Karacanın Mehmed } \\
\text { bin Ömer }\end{array}$ \\
\hline $\begin{array}{l}\text { Himmet oğlu } \\
\text { Mehmed bin } \\
\text { Himmet }\end{array}$ & $\begin{array}{c}\text { Himmet oğlu Ahmed } \\
\text { bin Himmet }\end{array}$ & $\begin{array}{l}\text { Minnet oğlu Kara } \\
\text { Hüseyin bin Ali }\end{array}$ \\
\hline $\begin{array}{l}\text { Hacı Süle } \\
\text { İdris bin S }\end{array}$ & $\begin{array}{c}\text { Barutcu oğlu Hasan } \\
\text { bin Halil }\end{array}$ & $\begin{array}{c}\text { Çavuş oğl } \\
\text { bin }\end{array}$ \\
\hline $\begin{array}{l}\text { Hasancık oğlu Berber } \\
\text { İsmail bin Hüseyin }\end{array}$ & $\begin{array}{c}\text { Ömer oğlu Ibrahim } \\
\text { bin Halil }\end{array}$ & $\begin{array}{l}\text { Çil Hasan oğlu } \\
\text { Hüseyin bin Ali }\end{array}$ \\
\hline $\begin{array}{c}\text { Çil Hasan oğlu } \\
\text { Mustafa bin İbrahim }\end{array}$ & $\begin{array}{l}\text { Üçdirem (?) oğlu } \\
\text { Halil bin İbrahim }\end{array}$ & $\begin{array}{c}\text { Kara Ali oğlu Berber } \\
\text { Ali bin Halil }\end{array}$ \\
\hline $\begin{array}{c}\text { Cihan oğlu İdris bin } \\
\text { Ibrahim }\end{array}$ & $\begin{array}{c}\text { Cihan oğlu Mustafa } \\
\text { bin Emin }\end{array}$ & $\begin{array}{c}\text { Bodur oğlu Halil bin } \\
\text { Ali }\end{array}$ \\
\hline $\begin{array}{l}\text { Hüseyni oğlu Hasan } \\
\text { bin Mehmed }\end{array}$ & $\begin{array}{c}\text { Serdar oğlu Mehmed } \\
\text { bin Osman }\end{array}$ & $\begin{array}{c}\text { Taranık oğlu İbrahim } \\
\text { bin Mustafa }\end{array}$ \\
\hline $\begin{array}{l}\text { Barutcu oğlu İbrahim } \\
\text { bin Ömer }\end{array}$ & $\begin{array}{l}\text { Bodur oğlu illyas bin } \\
\text { Ali }\end{array}$ & $\begin{array}{c}\text { Sarı oğlu İsmail bin } \\
\text { Mustafa }\end{array}$ \\
\hline $\begin{array}{l}\text { Bodur oğlu Emin bin } \\
\text { Ahmed }\end{array}$ & $\begin{array}{c}\text { Gevrek oğlu } \\
\text { Muhammed bin Halil }\end{array}$ & $\begin{array}{l}\text { Cihan oğlu Osman } \\
\text { bin Ömer }\end{array}$ \\
\hline $\begin{array}{c}\text { Derviş oğlu Hasan } \\
\text { bin Ali }\end{array}$ & $\begin{array}{l}\text { Sarıoglan oğlu } \\
\text { Mehmed bin } \\
\text { Hüseyin }\end{array}$ & $\begin{array}{l}\text { Devecinin oğlu } \\
\text { Hasan bin } \\
\text { Muhammed }\end{array}$ \\
\hline
\end{tabular}

${ }^{11}$ Kasımlar Köyü’nde ikamet eden hane reisleri ve ailelerinin adları için bkz. Tablo 1.

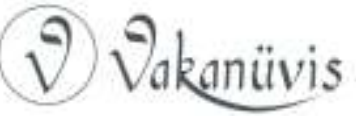




\begin{tabular}{|c|c|c|}
\hline $\begin{array}{c}\text { Çalık oğlu } \\
\text { Muhammed bin } \\
\text { Ahmed }\end{array}$ & $\begin{array}{l}\text { Manda oğlu Hüseyin } \\
\text { bin Eyüb }\end{array}$ & $\begin{array}{c}\text { Hasancık oğlu Ali bin } \\
\text { Halil }\end{array}$ \\
\hline $\begin{array}{l}\text { Devecinin Ali bin } \\
\text { Mehmed }\end{array}$ & $\begin{array}{l}\text { Çavuş oğlu Ömer bin } \\
\text { Ali }\end{array}$ & $\begin{array}{l}\text { Minnet oğlu Emin } \\
\text { bin Memiş }\end{array}$ \\
\hline $\begin{array}{l}\text { Kırk oğlu Eyüb bin } \\
\text { Ibrahim }\end{array}$ & $\begin{array}{l}\text { Halil oğlu Ibrahim } \\
\text { bin Ahmed }\end{array}$ & $\begin{array}{c}\text { Çakır oğlu Mehmed } \\
\text { bin Halil }\end{array}$ \\
\hline $\begin{array}{l}\text { Hasancık oğlu } \\
\text { İbrahim bin Ali }\end{array}$ & $\begin{array}{l}\text { Bakir oğlu Molla } \\
\text { Hüseyin bin Bekir }\end{array}$ & $\begin{array}{c}\text { Bekir oğlu Mustafa } \\
\text { bin Bekir }\end{array}$ \\
\hline $\begin{array}{l}\text { Çavuş Bekir oğlu } \\
\text { Ahmed bin Bekir }\end{array}$ & $\begin{array}{c}\text { Nebi oğlu Ahmed bin } \\
\text { Nebi }\end{array}$ & $\begin{array}{c}\text { Çolak oğlu Ibrahim } \\
\text { bin Bekir } \\
\end{array}$ \\
\hline $\begin{array}{l}\text { Celil oğlu Ali bin } \\
\text { Abdullah }\end{array}$ & $\begin{array}{l}\text { Karaoğlan oğlu } \\
\text { Hüseyin bin } \\
\text { Muhammed }\end{array}$ & $\begin{array}{c}\text { Karaoğlan oğlu } \\
\text { İbrahim bin Mehmed }\end{array}$ \\
\hline $\begin{array}{l}\text { Karaoğlan oğlu } \\
\text { Hasan bin } \\
\text { Muhammed }\end{array}$ & $\begin{array}{c}\text { Ömer Bey oğlu } \\
\text { Osman bin Ömer }\end{array}$ & $\begin{array}{c}\text { Devresi (?) oğlu } \\
\text { Devresi bin Mehmed }\end{array}$ \\
\hline $\begin{array}{l}\text { Nebi oğlu Mustafa } \\
\text { bin Emin }\end{array}$ & $\begin{array}{l}\text { Hacı Süleyman oğlu } \\
\text { Mustafa bin } \\
\text { Mehmed }\end{array}$ & $\begin{array}{l}\text { Hacı Süleyman oğlu } \\
\text { Süleyman bin } \\
\text { Mehmed }\end{array}$ \\
\hline $\begin{array}{l}\text { Hacı Süleyman’ın Ali } \\
\text { bin Muhammed }\end{array}$ & $\begin{array}{c}\text { Koca Muhammed } \\
\text { oğlu Muhammed bin } \\
\text { Devresi (?) }\end{array}$ & $\begin{array}{c}\text { Çelik oğlu Musa bin } \\
\text { Mustafa }\end{array}$ \\
\hline $\begin{array}{l}\text { Minaz (?) oğlu Halil } \\
\text { bin Mehmed }\end{array}$ & $\begin{array}{l}\text { Berber Ömer oğlu } \\
\text { Ömer bin Hüseyin }\end{array}$ & $\begin{array}{c}\text { Bursalı oğlu Halil bin } \\
\text { Ahmed }\end{array}$ \\
\hline $\begin{array}{c}\text { Çoban oğlu Ali bin } \\
\text { Ibrahim }\end{array}$ & $\begin{array}{c}\text { Hacı oğlu Hüseyin } \\
\text { bin Ali }\end{array}$ & $\begin{array}{c}\text { Ali oğlu İbrahim bin } \\
\text { Ali }\end{array}$ \\
\hline $\begin{array}{c}\text { Pirli oğlu } \\
\text { Muhammed bin } \\
\text { Ibrahim } \\
\end{array}$ & Pirli oğlu Veli bin Veli & $\begin{array}{l}\text { Hodal oğlu İbrahim } \\
\text { bin Satılmış }\end{array}$ \\
\hline $\begin{array}{c}\text { Kocabaş el-Hac Emin } \\
\text { bin Hasan }\end{array}$ & $\begin{array}{l}\text { Hodal oğlu Hüseyin } \\
\text { bin Satılmış }\end{array}$ & $\begin{array}{l}\text { Derviş oğlu Hüseyin } \\
\text { bin Ali }\end{array}$ \\
\hline $\begin{array}{c}\text { Kocabaş oğlu Ali bin } \\
\text { Hüseyin }\end{array}$ & $\begin{array}{l}\text { Kocabaş oğlu Yusuf } \\
\text { bin Hüseyin }\end{array}$ & $\begin{array}{l}\text { Aygır oğlu Kara } \\
\text { Mustafa bin Latif }\end{array}$ \\
\hline $\begin{array}{c}\text { Aygır oğlu } \\
\text { Muhammed bin Latif }\end{array}$ & $\begin{array}{l}\text { Aygır oğlu Molla Ali } \\
\text { bin Latif }\end{array}$ & $\begin{array}{l}\text { Kıraç Molla Osman } \\
\text { bin İsmail }\end{array}$ \\
\hline
\end{tabular}




\begin{tabular}{|c|c|c|}
\hline $\begin{array}{c}\text { Çoban oğlu Hüseyin } \\
\text { bin Mustafa }\end{array}$ & $\begin{array}{c}\text { Hüseyni oğlu Emin } \\
\text { bin Muhammed }\end{array}$ & $\begin{array}{c}\text { Eğriboyun bin } \\
\text { Rüstem }\end{array}$ \\
\hline $\begin{array}{c}\text { Derviş oğlu Ahmed } \\
\text { bin Mustafa }\end{array}$ & $\begin{array}{c}\text { Kocabaş oğlu } \\
\text { Mehmed Ali bin } \\
\text { Muhammed }\end{array}$ & $\begin{array}{c}\text { Hasancık oğlu Hacı } \\
\text { Abdullah bin Hasan }\end{array}$ \\
\hline $\begin{array}{c}\text { Aygır oğlu Yusuf bin } \\
\text { Latif }\end{array}$ & $\begin{array}{c}\text { Aygır oğlu Hasan bin } \\
\text { Latif }\end{array}$ & $\begin{array}{c}\text { Hasancık oğlu Halil } \\
\text { bin Hacı Abdullah }\end{array}$ \\
\hline $\begin{array}{c}\text { Ömer oğlu Halil bin } \\
\text { Latif }\end{array}$ & $\begin{array}{c}\text { Gülümbeli oğlu Ali } \\
\text { bin Abdullah }\end{array}$ & Abdullah bin Halil \\
\hline $\begin{array}{c}\text { Yeni Hasan oğlu Halil } \\
\text { bin Hasan }\end{array}$ & & \\
\hline
\end{tabular}

\section{Hane Reislerinin Meslekleri}

Temettuât Defteri incelendiğinde 1844 senesi itibarıyla Kasımlar Köyü'ndeki vergi mükelleflerinin 4 farklı meslekle meşgul oldukları anlaşılmaktadır. Bunlardan zirâatla 59, amelelikle 34, berberlikle 1 ve nalbantlıkla 1 kişi uğraşmaktadır. 2 kişinin de mesleği belirtilmemiştir. Mesleklerin oransal dağılımı ise \%60,84 zirâat, \%35 amele, \%1,05 berber, \%1,05 nalbant şeklindedir. Defterde meslekleri belirtilmeyenlerden biri Hacı oğlu Hacı Hasan bin Hacı Abdullah ve diğeri Kırk oğlu Eyüb bin İbrahim'dir. 1/1 numaralı hanede ikamet eden ve senelik geliri 1.810 kuruş olarak belirtilen Hacı Hasan'ın mesleğinin neden kaydedilmediğine dair bir malumat bulunmamaktadır. Buna karşıık 45/2 numaralı hanede ikamet eden Eyüb ile ilgili "Merkumun sâkin olduğu hânesinden başkaca bir şeysi olmayub ameleliğe dahi kudreti olmayarak şunun bunun iânesiyle geçinmekde olduğu" şeklinde bir not düşülerek herhangi bir işle uğraşmadığı açıklanmıştır. ${ }^{12}$

$\mathrm{Bu}$ verilerden anlaşılacağı üzere Kasımlar Köyü'ndeki vergi mükelleflerinin ekseriyeti zirâat ve muhtemelen onunla bağlantılı amelelik işi yapmaktadır. Bu durum köydeki sosyal ve ekonomik yapıyı belirleyen faktörün ziraî faaliyetler olduğunu göstermektedir.

12 Kasımlar Köyü’nde ikamet eden hane reislerinin meslekî yapılanması hakkında bkz. Tablo 2.

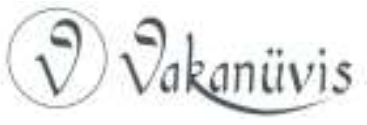


Tablo 2. Kasımlar Köyü’nde İkamet Eden Hane Reislerinin Meslekî Yapılanması

\begin{tabular}{|c|c|c|}
\hline Meslek Adı & $\begin{array}{c}\text { Meslek Sahibi Vergi } \\
\text { Mükellefi Sayısı }\end{array}$ & $\begin{array}{c}\text { Mesleğin Temsil } \\
\text { Edilme Oranı (\%) }\end{array}$ \\
\hline Zirâat & 59 & 60,84 \\
\hline Amele & 34 & 35 \\
\hline Berber & 1 & 1,05 \\
\hline Nalbant & 1 & 1,05 \\
\hline $\begin{array}{c}\text { Mesleği } \\
\text { Belirtilmeyenler }\end{array}$ & 2 & 2,06 \\
\hline Toplam & 97 & 100 \\
\hline
\end{tabular}

\section{2- Zirâat}

Temettuât Defterlerinde tahriri yapılan yerleşim yerlerinde ikamet eden hane reislerinin tasarrufundaki arazilerin mahiyeti ve ürettikleri ürünler hakkında önemli veriler bulunmaktadır. Bu veriler hane reislerinin işledikleri ve nadasa bıraktıkları arazilerin miktarları, hangi tür ürünün ekimi ve üretimiyle meşgul oldukları gibi hususlarda bazı değerlendirmeler yapmayı mümkün kılmaktadır. Kasımlar Köyü’ne ait defter incelendiğinde 1844'te ziraî üretim yapmaya elverişli arazi miktarının toplam 1.249,35 dönüm olduğu anlaşılmaktadır. Bu 1.249,35 dönüm arazinin $934^{\prime}$ üne hububat ve pamuk ekildiği, $28^{\prime}$ inin nadasa bırakıldığı, 120,125'inin bağ ve 167,225'inin de ipek böcekçiliği için harir bahçesi (dutluk) olarak kullanıldığı görülmektedir. Başka bir ifadeyle arazinin $\% 74,76$ 'sına hububat ve pamuk ekimi yapıldığı, \%2,24'ünün nadasa bırakıldığı, \%9,6'sının bağ ve \%13,4'ünün harir bahçesi şeklinde değerlendirildiği ortaya çıkmaktadır. Hane başına 10,04'ü hububat ve pamuk ekilen, 0,3'ü nadasa bırakılan, 1,79'u harir bahçesi ve 1,29'u bağ olmak üzere toplam 13,42 dönüm arazi düşmektedir. Hanelerden 91'i bu arazi türlerinden dönümleri değişmekle birlikte en az birine sahiptir. Buna karşılık 45/2 ile 60/1 numaralı hanelerde ikamet eden Kırk oğlu Eyüb bin İbrahim ve Nebi oğlu Mustafa bin Emin'in zirâat yapabilecekleri herhangi bir arazisi bulunmamaktadır. ${ }^{13}$ Bu dönemde Hüdavendigâr Eyâleti'ne bağlı Bilecik Kazası kırsalındaki köylerde ise arazilerin

${ }^{13}$ Kasımlar Köyü'nde ikamet eden hane reislerinin tasarrufundaki arazilerin dağılımı için bkz. Tablo 3.

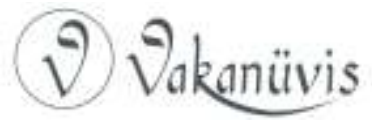


$\% 36,03$ 'üne hububat ve tarla ürünleri ekildiği, \%36,56'sının nadasa bırakıldığı, \%20,04'ünün harir bahçesi ve \%6,35'inin bağ olduğu görülmektedir. Hane başına ortalama 6,09 hububat ve tarla ürünleri ekili, 6,17 nadasa bırakılan, 3,3 harir bahçesi ve 1,07 bağ olmak üzere toplam 16,63 dönüm arazi düşmektedir. ${ }^{14}$

Tablo 3. Kasımlar Köyü'ndeki Hane Reislerinin Tasarrufundaki Arazilerin Dağılımı

\begin{tabular}{|c|c|c|c|}
\hline Arazi Türü & $\begin{array}{c}\text { Miktar } \\
\text { (Dönüm) }\end{array}$ & Oranı (\%) & $\begin{array}{c}\text { Hane Başına } \\
\text { Düşen Miktar } \\
\text { (Dönüm) }\end{array}$ \\
\hline $\begin{array}{c}\text { Hububat ve } \\
\text { Pamuk Ekili } \\
\text { Tarla }\end{array}$ & 934 & 74,76 & 10,04 \\
\hline Nadas Tarla & 28 & 2,24 & 0,3 \\
\hline $\begin{array}{c}\text { Harir Bahçesi } \\
\text { (Dutluk) }\end{array}$ & 167,225 & 13,4 & 1,79 \\
\hline Bağ & 120,125 & 9,6 & 1,29 \\
\hline Toplam & $1.249,35$ & 100 & 13,42 \\
\hline
\end{tabular}

XX. yüzyıl başlarındaki tarım istatistiklerinde Osmanlı Devleti'ndeki arazilerin büyüklüklerine göre sınıflandırıldıkları bilinmektedir. Bu istatistiklerde ailelerin tasarruflarında olup ektikleri ve nadasa bıraktıkları araziler mülkiyet özelliklerine bakılmaksızın üç gruba ayrılmıştır. Arazilerden yüzölçümleri 10 dönümden az olanlar küçük, 1050 dönüm arasındakiler orta ve 50 dönümün üzerindekiler de büyük işletmeler şeklinde değerlendirilmiştir. ${ }^{15} \mathrm{Bu}$ çerçevede Kasımlar Köyü'ndeki hububat ve pamuk ekilen, nadasa bırakılan, harir bahçesi ve bağ şeklinde kullanılan toplam 1.249,35 dönüm arazi sınıflandırıldığında 93 haneden 4'ünün büyük, 44'ünün orta ve 42'sinin küçük boy tarım işletmesine sahip oldukları anlaşılmaktadır. Hanelerden 3'ünün ise ekim yapabileceği veya nadasa bırakabileceği herhangi bir arazisi

14 Öztürk, a.g.e., s. 122, 138, 140-141, 143-144, 150.

15 Tevfik Güran, “Osmanlı Tarım Ekonomisi, 1840-1910”, 19. Yüzyılda Osmanlı Ekonomisi Üzerine Araştırmalar, Türkiye İş Bankası Kültür Yayınları, İstanbul 2019, s. 91.

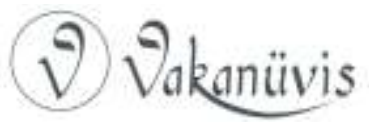


bulunmamaktadır. ${ }^{16}$ Oransal olarak hesaplandığında hanelerden $\% 4,3$ 'ünün büyük, $\% 47,3$ 'ünün orta ve $\% 45,1^{\prime}$ inin küçük boy tarım işletmesine sahip oldukları görülmektedir. Ekim yapmak ve nadasa bırakmak üzere herhangi bir arazisi bulunmayan hanelerin oranı da \% 3,3'tür. Diğer taraftan, arazi miktarlarına göre bir değerlendirme yapıldığında Kasımlar Köyü'ndeki toprakların \%19,61'inin büyük, $\% 64,83$ 'ünün orta ve \%15,56'sının küçük boy tarım işletmelerinin elinde olduğu ortaya çıkmaktadır. Ayrıca, hanelere ortalama olarak büyük boy işletmede 61,25 , orta boy işletmede 18,4 ve küçük boy işletmede de 4,62 dönüm arazi düştüğü görülmektedir. ${ }^{17}$

Tablo 4. Kasımlar Köyü’ndeki Tarım İşletmelerinin Dağılımı

\begin{tabular}{|c|c|c|c|c|c|}
\hline $\begin{array}{c}\text { Işletme } \\
\text { Türü }\end{array}$ & $\begin{array}{c}\text { Arazi } \\
\text { Miktarı } \\
\text { (Dönüm) }\end{array}$ & $\begin{array}{c}\text { Hane } \\
\text { Sayısı }\end{array}$ & $\begin{array}{c}\text { Hanelerin } \\
\text { Oranı (\%) }\end{array}$ & $\begin{array}{c}\text { Işletme } \\
\text { Başına } \\
\text { Düşen } \\
\text { Ortalama } \\
\text { Arazi } \\
\text { Miktarı } \\
\text { (Dönüm) }\end{array}$ & $\begin{array}{c}\text { işletmenin } \\
\text { Elindeki } \\
\text { Arazinin } \\
\text { Oranı (\%) }\end{array}$ \\
\hline $\begin{array}{c}\text { Büyük Boy } \\
\text { Tarım } \\
\text { Işsletmesi }\end{array}$ & 245 & 4 & 4,3 & 61,25 & 19,61 \\
\hline $\begin{array}{c}\text { Orta Boy } \\
\text { Tarım } \\
\text { Işletmesi }\end{array}$ & 810 & 44 & 47,3 & 18,4 & 64,83 \\
\hline $\begin{array}{c}\text { Küçük Boy } \\
\text { Tarım } \\
\text { Işsletmesi }\end{array}$ & 194,34 & 42 & 45,1 & 4,62 & 15,56 \\
\hline $\begin{array}{c}\text { Ekili ve } \\
\text { Nadas } \\
\text { Araziye }\end{array}$ & - & 3 & 3,3 & - & - \\
\hline
\end{tabular}

16 63/1 numaralı hanede ikamet eden Çelik oğlu Musa bin Mustafa'nın dört arazi türünden sadece harir bahçesi bulunmaktadır. Defterde bu harir bahçesinin hasılatı kaydedilmekle birlikte dönümü verilmemiştir. Bundan dolayı Çelik oğlu Musa bin Mustafa'nın hanesi "Ekili ve Nadas Araziye Sahip Olmayanlar" grubu içerisinde değerlendirilmiştir. Bkz. BOA, ML. VRD. TMT. d., nr. 8044, s. 34.

${ }^{17}$ Kasımlar Köyü'ndeki tarım işletmeleri hakkında bkz. Tablo 4.

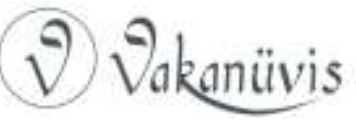




\begin{tabular}{|c|c|c|c|c|c|}
\hline $\begin{array}{c}\text { Sahip } \\
\text { Olmayanlar }\end{array}$ & & & & & \\
\hline Toplam & $1.249,35$ & 93 & 100 & 84,27 & 100 \\
\hline
\end{tabular}

Kasımlar Köyü'nde zirâat yapmaya müsait ekilebilir arazilerde buğday, arpa, burçak gibi tahıl ürünleri, pamuk ve üzüm yetiştirildiği görülmektedir. Yukarıda zikredildiği üzere, ekilebilir arazilerin önemli bir bölümü ise ipek böcekçiliği için harir bahçesi olarak ayrılmıştır. Defterde pamuk ve üzümün ne kadar üretildiklerine dair düzenli veri bulunmamaktadır. Bundan dolayı üretilen tahıl ürünleri ile ilgili genel bir değerlendirme yapılmaya çalışılacaktır. Defter incelendiğinde Kasımlar Köyü'ndeki 93 haneden 78'inin $(\% 83,9)$ tahıl üretimiyle uğraştığı görülmektedir. 1844 senesi itibarıla üretilen toplam 3.005 kile $^{18}$ $(74.609,9 \mathrm{~kg})$ tahılın $2.270(58.239,12 \mathrm{~kg})^{\prime} i$ buğday, $730(16.242,5 \mathrm{~kg})^{\prime} \mathrm{u}$ arpa ve $5(128,28 \mathrm{~kg})^{\prime} i$ burçaktır. Oransal bakımından tahıl üretiminin $\% 75,54$ 'ünün buğday, $\% 24,29$ 'unun arpa ve $\% 0,17$ 'sinin burçak olduğu anlaşılmaktadır. Hane başına ortalama 24,40 (626 kg) buğday, 7,84 $(174,44 \mathrm{~kg})$ arpa ve 0,053 (1,35 kg) burçak olmak üzere toplam 32,293 kile $(801,79 \mathrm{~kg})$ civarında tahıl düşmektedir. ${ }^{19}$

Bu verilerden de anlaşılacağı üzere, tahıl ürünleri içerisinde en fazla üretilen insanların temel besin maddelerinden birisi olan buğdaydır. XIX. yüzyılda bölgeye göre değişmekle birlikte Osmanlı Devleti'nde buğday tüketiminin kişi başı 190-235 kg arasında değiştiği ifade edilmektedir. ${ }^{20}$ Temettuât tahrirlerinin yapıldığı 1845 senesi itibarıyla Kasımlar

18 Osmanlı Devleti'nde 1841 senesinden itibaren resmî İstanbul kilesi buğdayda 25,656 kg (20 okka) ve arpada 22,25 kg (17,35 okka) olarak işlem görmekteydi (Walther Hinz, “İslâm'da Ölçü Sistemleri”, Marmara Üniversitesi Türklük Araştırmaları Dergisi, Çev. Acar Sevim, 5, İstanbul 1989, s. 51). Bu çalışmada arpa 22,25 kg ve diğer tahıl ürünleri ise $25,656 \mathrm{~kg}$ üzerinden hesaplanmıştır.

${ }^{19}$ Defterde hane reislerinin 1844 senesi itibarıyla ne tür tahıl ürettikleri ve ürünlerin kile cinsinden ne kadarını öşür vergisi olarak devlete verdikleri ve bunların o günkü şartlarda rayiç karşılıkları kaydedilmiştir. Dolayısıyla defterin bu kısmındaki rakamlar 10'la çarpıldığında hane reislerinin her bir üründen veya toplam ne kadar kile tahıl üretimi gerçekleştirdikleri tahminî olarak hesaplanabilmektedir (Kütükoğlu, a.g.m., s. 406). Hanelerin tahıl üretiminin hesaplanmasında bu yol izlenmiştir. Kasımlar Köyü’nde hane reislerinin ürettikleri tahılın dağılımı için bkz. Tablo 5 .

${ }^{20}$ Güran, "Osmanlı Tarım Ekonomisi", s. 104.

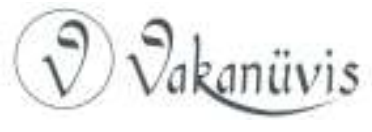


Köyü’nün tahminî nüfusu ise 465 kişidir. Köydeki kişilerin tamamının buğday unu ile beslendikleri varsayılırsa senelik tüketim en az $88.350 \mathrm{~kg}$ olmaktadır. Üretilen toplam $(58.239,12 \mathrm{~kg})$ buğdayın yaklaşık beşte birinin $(11.647,8 \mathrm{~kg})$ sonraki sene için tohum olarak ayrılacağı da düşünüldüğünde ${ }^{21} 41.758,7$ kg üretim açığı ortaya çıkmaktadır. Bu durumda Kasımlar Köyü'nün ihtiyacının tamamını karşılayacak kadar buğday üretimi gerçekleştiremediğini ve eksik kalan miktarı dışarıdan tedarik etmek zorunda olduğunu belirtmek mümkündür.

Tablo 5. Kasımlar Köyü'nde Hane Reislerinin Ürettikleri Tahılın Dağılımı

\begin{tabular}{|c|c|c|c|}
\hline Ürün Çeşidi & Miktar (Kile) & Oranı (\%) & $\begin{array}{c}\text { Hane Başına } \\
\text { Düşen Miktar } \\
\text { (Kile) }\end{array}$ \\
\hline Buğday & 2.270 & 75,54 & 24,40 \\
\hline Arpa & 730 & 24,29 & 7,84 \\
\hline Burçak & 5 & 0,17 & 0,053 \\
\hline Toplam & 3.005 & 100 & 32,293 \\
\hline
\end{tabular}

\section{3- Hayvancilık}

Osmanlı Devleti'nin kırsal bölgelerindeki hayvan yetiştiriciliği geleneksel tarımın tamamlayıcı parçalarından birisidir. Bu bölgelerde hayvanlar çekim ve yük taşımada güçlerinden yararlanmak ve peynir, yağ, süt, et, deri, yün, gübre gibi ihtiyaçları karşılamak için yetiştirilmişlerdir. ${ }^{22}$ Kasımlar Köyü'nde ikamet eden hanelerin de genellikle bu amaçlarla hayvancılık yaptıkları tahmin edilebilir. Defter incelendiğinde 1844 senesi itibarıyla Kasımlar Köyü'ndeki hayvansal varlığın toplam 500 adet olduğu görülmektedir. Hanelerden 73 $(\% 78,5)$ 'ü en az bir hayvana sahiptir. Buna karşılık 20 adet $(\% 21,5)$ hanenin herhangi bir hayvanı bulunmamaktadır. Hayvansal varlığın 180 (\%36)'i büyükbaş, $248(\% 49,6)^{\prime}$ i küçükbaş ve 72 (\%14,4)'si yük-binek

\footnotetext{
${ }^{21}$ Nurgül Bozkurt, "1844-1845 Tarihli Temettüat Defterine Göre Kütahya Sancağı Dazkırı Kazası Evciler Köyü’nün Sosyal ve Ekonomik Yapısı”, Uluslararası Sosyal Araştırmalar Dergisi, IV/19, (2011), s. 149.

22 Güran, "Osmanlı Tarım Ekonomisi”, s. 121.
} 
grubuna girmektedir. Hanelerden 65'i büyükbaş, 3'ü küçükbaş ve 64 'ü yük-binek hayvanlarına sahiptir ve hane başına sırasıyla ortalama 2,76 , 82,66 ve 1,12 olmak üzere toplam 86,54 baş hayvan düşmektedir. ${ }^{23}$

Tablo 6. Kasımlar Köyü’nde Hane Reislerinin Sahip Oldukları Hayvan Çeşitleri

\begin{tabular}{|c|c|c|c|c|}
\hline $\begin{array}{c}\text { Hayvan } \\
\text { Çeşidi }\end{array}$ & $\begin{array}{c}\text { Hayvan } \\
\text { Sayısı }\end{array}$ & Oranı (\%) & $\begin{array}{c}\text { Hayvan } \\
\text { Sahibi } \\
\text { Hane } \\
\text { Sayısı }\end{array}$ & $\begin{array}{c}\text { Hane } \\
\text { Başına } \\
\text { Düşen } \\
\text { Hayvan } \\
\text { (Baş) }\end{array}$ \\
\hline Büyükbaş & 180 & 36 & 65 & 2,76 \\
\hline Küçükbaş & 248 & 49,6 & 3 & 82,66 \\
\hline Yük ve Binek & 72 & 14,4 & 64 & 1,12 \\
\hline Toplam & 500 & 100 & 132 & 86,54 \\
\hline
\end{tabular}

\section{Büyükbaş Hayvancılık}

Defter incelendiğinde Kasımlar Köyü'ndeki hane reislerinin büyükbaş hayvan olarak inek, öküz, düğe (düve) ve dana besledikleri görülmektedir. 180 adet büyükbaş hayvandan 108 (\%60)'i öküz, 31 $(\% 17,22)^{\prime}$ i sağmal inek, $14(\% 7,78)$ 'ü dana, 13 (\%7,22)'ü yoz inek, 11 $(\% 6,11)^{\prime}$ i düğe (düve) ve $3(\% 1,67)$ 'ü yoz düğedir. Hanelerden 58 'i öküz, $31^{\prime} i$ sağmal inek, 14'ü dana, 13'ü yoz inek, $11^{\prime} i$ düğe ve 3'ü yoz düğe sahibidir. Hane başına ortalama 1,86 öküz ve 1'er sağmal inek, dana, yoz inek, düğe ve yoz düğe olmak üzere toplam 6,86 baş hayvan düşmektedir. ${ }^{24}$

Osmanlı Devleti'nde zirâatla uğraşanların çift sürmede modern araçlardan yeteri düzeyde yararlanma imkânı bulamadıkları ve bunun yerine başta öküz olmak üzere at ve katır kullandıkları bilinmektedir. Ancak öküzler eğimli ve dik topraklarda çift sürmek için verimlilikleri ve senelik beslenme giderlerinin at veya katırlara oranla az olması

\footnotetext{
${ }^{23}$ Kasımlar Köyü’nde hane reislerinin sahip oldukları hayvan çeşitleri için bkz. Tablo 6.

${ }^{24}$ Kasımlar Köyü’nde hane reislerinin sahip oldukları büyükbaş hayvan çeşitleri için bkz. Tablo 7.
}

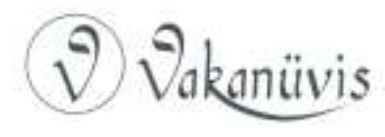


nedeniyle daha fazla tercih edilmişlerdir. ${ }^{25}$ Bu durum Kasımlar Köyü'nde büyükbaş hayvan olarak 108 adetle en fazla öküz beslenmesiyle de teyit edilmektedir. Ancak öküz sahibi hanelere ortalama 1,86 baş hayvan düşmektedir. Dolayısıyla bu hanelerden bazılarının çift sürme işinde yeterli miktarda öküze sahip olmadıklarını belirtmek mümkündür.

Tablo 7. Kasımlar Köyü’nde Hane Reislerinin Sahip Oldukları Büyükbaş Hayvan Çeşitleri

\begin{tabular}{|c|c|c|c|c|}
\hline $\begin{array}{c}\text { Hayvan } \\
\text { Çeşidi }\end{array}$ & $\begin{array}{c}\text { Hayvan } \\
\text { Sayısı }\end{array}$ & Oranı (\%) & $\begin{array}{c}\text { Hayvan } \\
\text { Sahibi } \\
\text { Hane Sayısı }\end{array}$ & $\begin{array}{c}\text { Hane } \\
\text { Başına } \\
\text { Düşen } \\
\text { Hayvan } \\
\text { (Baş) }\end{array}$ \\
\hline Sağmal İnek & 31 & 17,22 & 31 & 1 \\
\hline Yoz İnek & 13 & 7,22 & 13 & 1 \\
\hline Öküz & 108 & 60 & 58 & 1,86 \\
\hline Düğe & 11 & 6,11 & 11 & 1 \\
\hline Yoz Düğe & 3 & 1,67 & 3 & 1 \\
\hline Dana & 14 & 7,78 & 14 & 1 \\
\hline Toplam & 180 & 100 & 130 & 6,86 \\
\hline
\end{tabular}

\section{Küçükbaş Hayvancılık}

Ziraî faaliyetlerin gerçekleştirilmesinde doğrudan bir katkıSı bulunmayan küçükbaş hayvanlar, daha çok hanelerin et, süt, yağ, deri ve yün ihtiyaçlarını karşılamaları için yetiştirilmişlerdir. Defterdeki verilere göre 1844 senesi itibarıyla Kasımlar Köyü'nde küçükbaş hayvan olarak sağmal koyun, yoz koyun, kuzu, sağmal keçi, oğlak ve yoz keçi beslendiği görülmektedir. Bunların $106(\% 42,75)$ 'sı sağmal keçi, 51 $(\% 20,56)$ 'i oğlak, $45(\% 18,14)$ 'i yoz keçi, $21(\% 8,46)$ 'i sağmal koyun, 15 (\% 6,05)'i kuzu ve 10 (\% 4,04)'u yoz koyun olmak üzere toplam 248 baştır. Hanelerden 3'ü sağmal keçi, 2'si oğlak, 2'si yoz keçi, 3'ü sağmal koyun, 3'ü kuzu ve 1'i yoz koyuna sahiptir. Hanelere ortalama 35,3

${ }^{25}$ Güran, “Osmanlı Tarım Ekonomisi”, s. 97.

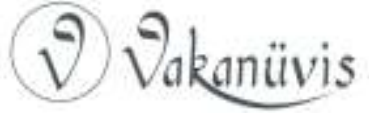


sağmal keçi, 22,5 oğlak ile yoz keçi, 10 yoz koyun, 7 sağmal koyun ve 5 kuzu olmak üzere toplam 102,3 adet küçükbaş hayvan düşmektedir. ${ }^{26}$

XIX. yüzyıl sonlarında Osmanlı Devleti'nde senede ortalama olarak bir koyundan 0,95 kg yün, bir tiftik keçisinden 1,9 kg tiftik ve bir kıl keçisinden de 0,375 kg kıl elde edilmekteydi. Defterlerde 1844 senesi itibarıyla Kasımlar Köyü'nde mevcut 151 keçi, kıl veya tiftik gibi tür ayırımı olmadan kaydedildiğinden üretime dair bir değerlendirmede bulunmak mümkün değildir. Bununla birlikte 31 adet sağmal ve yoz koyundan 29,45 kg kadar bir yün alındığı tahmin edilebilir. Bu durumda sağmal ve yoz koyun sahibi 4 adet hanenin her birine 7,36 kg yün düşmektedir. Hanelerin ürettikleri bu yünü yatak, minder yapmada; eğirip iplik haline getirdikten sonra kazak ve çorap örmede yahut tezgahlarında halı, kilim, heybe ve tahıl çuvalı dokumada kullandıkları belirtilebilir. ${ }^{27}$

Tablo 8. Kasımlar Köyü’nde Hane Reislerinin Sahip Oldukları Küçükbaş Hayvan Çeşitleri

\begin{tabular}{|c|c|c|c|c|}
\hline $\begin{array}{c}\text { Hayvan } \\
\text { Çeşidi }\end{array}$ & $\begin{array}{c}\text { Hayvan } \\
\text { Sayısı }\end{array}$ & Oranı (\%) & $\begin{array}{c}\text { Hayvan } \\
\text { Sahibi } \\
\text { Hane Sayısı }\end{array}$ & $\begin{array}{c}\text { Hane } \\
\text { Başına } \\
\text { Düşen } \\
\text { Hayvan } \\
\text { (Baş) }\end{array}$ \\
\hline $\begin{array}{c}\text { Sağmal } \\
\text { Koyun }\end{array}$ & 21 & 8,46 & 3 & 7 \\
\hline Yoz Koyun & 10 & 4,04 & 1 & 10 \\
\hline Kuzu & 15 & 6,05 & 3 & 5 \\
\hline Sağmal Keçi & 106 & 42,75 & 3 & 35,3 \\
\hline Yoz Keçi & 45 & 18,14 & 2 & 22,5 \\
\hline Oğlak & 51 & 20,56 & 2 & 25,5 \\
\hline Toplam & 248 & 100 & 14 & 102,3 \\
\hline
\end{tabular}

\footnotetext{
${ }^{26}$ Kasımlar Köyü'nde hane reislerinin sahip oldukları küçükbaş hayvanlar için bkz. Tablo 8.

${ }^{27}$ Bozkurt, a.g.m., s. 150.
} 


\section{Süt ve Süt Ürünleri Üretimi}

Sağılabilir büyük ve küçükbaş hayvanların ürettikleri en değerli ürünlerden birisi süttür. Süt ve ondan yapılan diğer ürünler protein, karbonhidrat, yağ, mineral ve vitamin açısından zengin içeriğe sahiptirler. Bu özelliklerinden dolayı süt ve süt ürünlerinin kırsal bölgelerde yoğun şekilde tüketildikleri ve intiyaçtan fazla olanlarının da pazarda satılarak hanelere ek gelir sağladıkları belirtilebilir. Büyükbaş hayvanlardan inek ve mandaların günlük sabah ve akşam iki defa olmak üzere on; küçükbaş hayvanlardan koyun beş ve keçi altı ay boyunca sağılmaktaydı. XX. yüzyıl başlarında Osmanlı Devleti'nde bölgesine ve hayvanın cinsine göre farklılıklar bulunmakla birlikte senede inek 192$770 \mathrm{~L}$ ve koyun 35-72 L civarında süt vermekteydi. ${ }^{28}$

$\mathrm{Bu}$ verilerin ortalamaları kullanılarak hesaplama yapıldığında sağılabilir 158 adet büyük ve küçükbaş hayvan bulunan Kasımlar Köyü'nde 1844 senesinde 21.705,5 L civarında süt üretimi gerçekleştirildiği anlaşılmaktadır. Bunun 14.911 L'si ineklerden, 5.671 L'si keçilerden ve 1.123,5 L'si de koyunlardan elde edilmiştir. Hane başına senelik ineklerden 160,33 L, keçilerden $60,97 \mathrm{~L}$ ve koyunlardan $12,08 \mathrm{~L}$ olmak üzere toplam $233,38 \mathrm{~L}$ süt düşmektedir. Hanelere günlük ise 0,63 L süt düşmektedir; bunun 0,44 L'sini inekler, 0,16 L'sini keçiler ve 0,033 L'sini de koyunlar sağlamışlardır. Büyük ve küçükbaş sağılabilir hayvan sahibi haneler içerisinde bir değerlendirme yapıldığında ise senelik ve günlük düşen süt miktarları değişmektedir. Bu durumda hane başına senelik 403 L'si ineklerden, 153,27 L'si keçilerden, 30,36 L'si koyunlardan olmak üzere toplam 586,63 L süt düşmektedir. Hanelere günlük düşen süt miktarı 15,85 L'dir; bunun 10,89 L'sini inekler, 4,14 L'sini keçiler ve 0,82 L'sini de koyunlar karşılamışlardır. ${ }^{29}$

Diğer taraftan, üretilen sütten bir kısmının yağ, peynir, yoğurt gibi ürünlerin yapımında değerlendirildiği muhakkaktır. Kasımlar Köyü’ndeki hanelerin senelik üretilen sütten ne kadarını bu tür ürünlerin yapımında kullandıklarını kesin rakamlarla ifade etmek güçtür. Ancak ortalama $1 \mathrm{~kg}$ yağın $20 \mathrm{~L}$ ve $1 \mathrm{~kg}$ peynirin de $5,5 \mathrm{~L}$ sütten elde edileceği

\footnotetext{
${ }^{28}$ Güran, "Osmanlı Tarım Ekonomisi", s. 126.

${ }^{29}$ Kasımlar Köyü’nde hane reislerinin süt üretimi için bkz. Tablo 9.
}

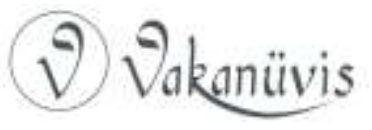


düşünüldügünde ${ }^{30} 1844$ senesinde üretilen toplam 21.705,5 L sütle $1.085,2 \mathrm{~kg}$ yağ veya $3.946,4 \mathrm{~kg}$ peynir yapılabileceğini belirtmek mümkündür.

Tablo 9. Kasımlar Köyü’nde Hane Reislerinin Süt Üretimi

\begin{tabular}{|c|c|c|c|c|}
\hline $\begin{array}{c}\text { Hayvan } \\
\text { Çeşidi }\end{array}$ & $\begin{array}{c}\text { Hayvan } \\
\text { Sayısı }\end{array}$ & $\begin{array}{c}\text { Senelik Süt } \\
\text { Üretimi (L) }\end{array}$ & $\begin{array}{c}\text { Senelik } \\
\text { Hane } \\
\text { Başına } \\
\text { Düşen Süt } \\
\text { (L) }\end{array}$ & $\begin{array}{c}\text { Günlük } \\
\text { Hane } \\
\text { Başına } \\
\text { Düşen Süt } \\
\text { (L) }\end{array}$ \\
\hline $\begin{array}{c}\text { Sağmal } \\
\text { Inek }\end{array}$ & 31 & 14.911 & 160,33 & 0,44 \\
\hline $\begin{array}{c}\text { Sağmal } \\
\text { Koyun }\end{array}$ & 106 & $1.123,5$ & 12,08 & 0,033 \\
\hline $\begin{array}{c}\text { Sağmal } \\
\text { Keçi }\end{array}$ & 21 & 5.671 & 60,97 & 0,16 \\
\hline Toplam & 158 & $21.705,5$ & 233,38 & 0,63 \\
\hline
\end{tabular}

\section{Yük ve Binek Hayvanları}

Kasımlar Köyü'ndeki hane reislerinin merkep (eşek), katır ve beygir (at) gibi yük-binek grubuna dâhil hayvanlar da yetiştirdikleri görülmektedir. Defter incelendiğinde 1844 senesi itibarıyla 38 $(\% 52,78)^{\prime} i$ merkep, 24 (\%33,33)'ü katır ve 10 (\%13,89)'u beygir olmak üzere toplam 72 baş yük-binek hayvanı bulunmaktadır. Hanelerden 37'si merkep, 23'ü katır ve 10'u katır sahibidir. Hanelere ortalama 1,02 merkep, 1,04 katır ve 1 beygir olmak üzere toplam 3,06 baş yük ve binek hayvanı düşmektedir. ${ }^{31}$

\footnotetext{
30 Güran, "Osmanlı Tarım Ekonomisi”, s. 126.

${ }^{31}$ Kasımlar Köyü'nde hane reislerinin sahip oldukları yük ve binek hayvanları hakkında bkz. Tablo 10.
}

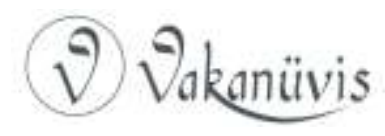


Tablo 10. Kasımlar Köyü’nde Hane Reislerinin Sahip Oldukları Yük ve Binek Hayvanı Çeşitleri

\begin{tabular}{|c|c|c|c|c|}
\hline $\begin{array}{c}\text { Hayvan } \\
\text { Çeşidi }\end{array}$ & $\begin{array}{c}\text { Hayvan } \\
\text { Sayısı }\end{array}$ & Oranı (\%) & $\begin{array}{c}\text { Hayvan } \\
\text { Sahibi } \\
\text { Hane Sayısı }\end{array}$ & $\begin{array}{c}\text { Hane } \\
\text { Başına } \\
\text { Düşen } \\
\text { Hayvan } \\
\text { (Baş) }\end{array}$ \\
\hline Merkep & 38 & 52,78 & 37 & 1,02 \\
\hline Katır & 24 & 33,33 & 23 & 1,04 \\
\hline Beygir & 10 & 13,89 & 10 & 1 \\
\hline Toplam & 72 & 100 & 70 & 3,06 \\
\hline
\end{tabular}

\section{4- Gelirler ve Vergilendirme}

Temettuât Defterlerinde tahriri yapılan yerleşim yerinde ikamet eden vergi mükellefi hane reislerinin gelir kalemleri, miktarları ve senelik toplamları kaydedilmiştir. Bu kayıt usulünün Kasımlar Köyü’ne ait defterde de herhangi bir değişiklik olmadan sürdürüldüğü görülmektedir. Defter incelendiğinde Kasımlar Köyü'ndeki hane reislerinin gelirlerini tarım, hayvancılık ve diğer işlerden elde ettikleri anlaşılmaktadır. Bunlardan tarım, ekili tarlalar, harir bahçeleri, üzüm bağlarını; hayvancılık, sağmal inek, koyun, keçi ile yoz koyun ve keçiyi; diğer grubu ise değirmenlerden elde edilen gelirleri kapsamaktadır. Değirmenler 1/1 ile 89/1 numaralı hanelerde ikamet eden Hacı oğlu Hacı Hasan bin Hacı Abdullah ve Hasancık oğlu Halil bin Hacı Abdullah aittir; her birinin senelik kazançları 1.500'er kuruştur. Ayrıca, 60/1 numaralı hanede ikamet eden Nebi oğlu Mustafa bin Emin'in senelik geliri defterde herhangi bir ayrım yapılmadan 200 kuruş olarak kaydedildiğinden diğer grubu içerisinde değerlendirilmiştir. 1844 senesi itibarıyla Kasımlar Köyü'ndeki hane reisleri $63.652,25^{\prime} \mathrm{i}$ tarım, 1.124'ü hayvancllık ve 3.200'ü diğer grubundan olmak üzere toplam 67.976,25 kuruş kazanç sağlamışlardır. Bunların oransal dağılımı da \%93,639 tarım, $\% 1,654$ hayvancılık ve \%4,707 diğer gelirler şeklindedir. Hane başına 
$684,43^{\prime}$ ü tarım, 12,08 'i hayvancılık ve 34,40 'ı diğer gelirlerden olmak üzere toplam 730,91 kuruş düşmektedir. ${ }^{32}$

Tablo 11. Kasımlar Köyü’nde Hane Reislerinin Gelirlerinin Dağılımı

\begin{tabular}{|c|c|c|c|}
\hline Gelir Grubu & Miktarı (Kuruş) & Oranı (\%) & $\begin{array}{c}\text { Hane Başına } \\
\text { Düşen Gelir } \\
\text { Miktarı } \\
\text { (Kuruş) }\end{array}$ \\
\hline Tarım & $63.652,25$ & 93,639 & 684,43 \\
\hline Hayvancılık & 1.124 & 1,654 & 12,08 \\
\hline Diğer Gelirler & 3.200 & 4,707 & 34,40 \\
\hline Toplam & $67.976,25$ & 100 & 730,91 \\
\hline
\end{tabular}

Kasımlar Köyü'ndeki hane reislerinin izah edilen bu kazançları karşılığında devlete iki kalem altında vergi vermeleri gerekmekteydi. Bunlardan biri üretilen ziraî ürünlerden $1 / 10$ oranında alınan öşür, diğeri ise 1840 'tan itibaren daha evvelki örfî vergilerin yerine tek tip olarak ikame edilmesi kararlaştırılan ve mükelleflerin senelik gelirleri üzerinden hesaplanarak toplanan temettü veya vergi-yi mahsusaydı. Defterdeki veriler incelendiğinde 1844 senesinde Kasımlar Köyü'ndeki hane reisleri $6.436,75^{\prime} i$ öşür ve 14.839 'u vergi-yi mahsusa ${ }^{33}$ olmak üzere devlete toplam 21.275,75 kuruş vergi ödemişlerdir. Bu vergi miktarı hane reislerinin 1844 senesinde elde ettikleri 67.976,25 kuruşluk toplam kazancın oransal olarak \%31,3'üne karşılık gelmektedir. Hane reislerinin devlete ödedikleri öşrü, ekili tarım arazilerinde üretilen ürünlerden, meyveden, ipek böcekçiliğinden ve hayvanlardan alınanlar olmak üzere

\footnotetext{
32 Kasımlar Köyü'nde hane reislerinin 1844 senesinde elde ettikleri gelirlerin dağılımı için bkz. Tablo 11. Bu dönemde Bilecik Kazası'ndaki köylerde ise hanelerin toplam gelirleri içerisinde tarımın \%91,42 ve hayvancılı̆ın $\% 1,52$ 'lik bir orana sahip olduğu görülmektedir (Öztürk, a.g.e., s. 111).

33 Defterin son sayfasında kaydedilen vergi-yi mahsusanın toplam miktarı 14.819 kuruştur. Ancak defterin içerisindeki her bir hanenin ödediği vergi-yi mahsusalar toplandığında 14.839 çıkmaktadır. Dolayısıyla defterin son sayfasında ve içlerinde kaydedilen vergi-yi mahsusaların genel toplamları arasında 20 kuruşluk bir fark çıkmaktadır. Çalışmada, defterin içerisindeki her bir hanenin ödediği vergi-yi mahsusaların toplanmasıyla elde edilen 14.839 kuruş kullanılmıştır.
}

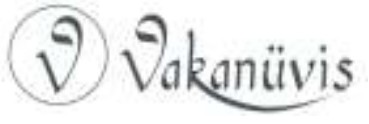


birçok alt kaleme ayırmak mümkündür. Devletin 1844 senesinde topladığı 6.436,75 kuruş öşrün bu alt kalemlere dağııımı ise ekili tarım arazilerinde üretilen ürünlerden 3.740 (\%58,103), meyveden 451,5 $(\% 7,015)$, ipek böcekçiliğinden $2.190,5(\% 34,031)$ ve hayvanlardan $54,75(\% 0,851)$ şeklindedir. Hane başına ekili tarım arazilerinde üretilen ürünlerden 40,193, meyveden 4,85, ipek böcekçiliğinden 23,55 ve hayvanlardan 0,58 olmak üzere toplam 69,173 kuruş öşür düşmektedir. ${ }^{34}$

Tablo 12. Kasımlar Köyü’nde Hane Reislerinin Verdikleri Öşür Vergisinin Dağılımı

\begin{tabular}{|c|c|c|c|c|}
\hline Vergi Türü & $\begin{array}{c}\text { Vergi } \\
\text { Miktarı } \\
\text { (Kuruş) }\end{array}$ & $\begin{array}{c}\text { Vergiyi } \\
\text { Ödeyen } \\
\text { Hane Sayısı }\end{array}$ & $\begin{array}{c}\text { Oranı } \\
\text { (\%) }\end{array}$ & $\begin{array}{c}\text { Hane } \\
\text { Başına } \\
\text { Düşen } \\
\text { Ortalama } \\
\text { Vergi } \\
\text { Miktarı }\end{array}$ \\
\hline $\begin{array}{c}\text { Ekili (Tarla) } \\
\text { Tarım Öşrü }\end{array}$ & & 77 & 48 & 33,22 \\
\hline Buğday & 3.090 & 46 & 9,08 & 6,27 \\
\hline Arpa & 584 & 2 & 0,062 & 0,043 \\
\hline Burçak & 4 & $\mathbf{5 7 , 1 4 2}$ & $\mathbf{3 9 , 5 3 3}$ \\
\hline $\begin{array}{c}\text { Hububat } \\
\text { Öşrü } \\
\text { Toplamı }\end{array}$ & $\mathbf{3 . 6 7 8}$ & & 0,961 & 0,66 \\
\hline Pamuk & 62 & 12 & $\mathbf{5 8 , 1 0 3}$ & $\mathbf{4 0 , 1 9 3}$ \\
\hline $\begin{array}{c}\text { Ekili (Tarla) } \\
\text { Tarım Öşrü } \\
\text { Toplamı }\end{array}$ & $\mathbf{3 . 7 4 0}$ & & & \\
\hline $\begin{array}{c}\text { Meyve Öşrü } \\
\text { Meymat }\end{array}$ & & & & \\
\hline
\end{tabular}

34 Kasımlar Köyü'ndeki hane reislerinin 1844 senesinde devlete ödedikleri öşür vergisinin dağılımı hakkında bkz. Tablo 12. Bu dönemde Hüdavendigâr Eyâleti dâhilindeki Bilecik Kazası'na bağlı köylerde hane reisleri ortalama 184,67'si vergi-yi mahsusa ve 145,79'u öşür olmak üzere toplam 330,46 kuruş vergi ödemişlerdir (Öztürk, a.g.e., s. 191, 195). Kasımlar Köyü'ndeki hane reislerinin vergi yükü toplamı ise 228,723 kuruştur.

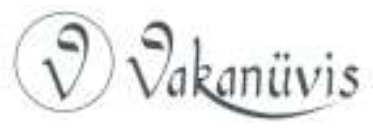




\begin{tabular}{|c|c|c|c|c|}
\hline Üzüm & 451,5 & 84 & 7,015 & 4,85 \\
\hline $\begin{array}{c}\text { Meyve Öşrü } \\
\text { Toplamı }\end{array}$ & $\mathbf{4 5 1 , 5}$ & $\mathbf{7 , 0 1 5}$ & $\mathbf{4 , 8 5}$ \\
\hline Harir Öşrü & $\mathbf{2 . 1 9 0 , 5}$ & 88 & $\mathbf{3 4 , 0 3 1}$ & $\mathbf{2 3 , 5 5}$ \\
\hline Hayvan Öşrü & & 3 & 0,851 & 0,58 \\
\hline $\begin{array}{c}\text { Adet-i } \\
\text { Ağnam }\end{array}$ & 54,75 & $\mathbf{5 4 , 7 5}$ & $\mathbf{0 , 8 5 1}$ & $\mathbf{0 , 5 8}$ \\
\hline $\begin{array}{c}\text { Hayvan Öşrü } \\
\text { Toplamı }\end{array}$ & $\mathbf{6 . 4 3 6 , 7 5}$ & $\mathbf{1 0 0}$ & $\mathbf{6 9 , 1 7 3}$ \\
\hline $\begin{array}{c}\text { Toplam Öşür } \\
\text { Miktarı }\end{array}$ & & & \\
\hline
\end{tabular}

\section{Sonuç}

Osmanlı Devleti'nin 1844-1845'teki idarî taksimatına göre Kasımlar Köyü, Hüdavendigâr Eyâleti dâhilindeki Gölpazarı Kazası'na bağlı bir yerleşim yeriydi. Köyde takribî 465 kişi ikamet etmekteydi ve bu nüfusun içerisinde herhangi bir gayrimüslim bulunmamaktaydı. Vergi mükellefi hanelerin geçimleri ise genel olarak tarım ve hayvancılığa dayanmaktaydı. 1844 senesinde hane reisleri $63.652,25^{\prime} \mathrm{i}$ tarım, 1.124'ü hayvancllık ve 3.200 'ü diğer grubundan olmak üzere toplam 67.976,25 kuruş kazanç sağlamışlardı. Bu kazançtan hanelerin her birine ortalama 730,91 kuruş düşmüştü.

Kasımlar Köyü'nde, ziraî üretim yapmaya elverişli toplam 1.249,35 dönüm arazi yer almaktaydı. 1844 senesi itibarıyla bu 1.249,35 dönüm arazinin $934(\% 74,76)$ 'üne hububat ve pamuk ekimi yapılmış, 28 $(\% 2,24)^{\prime} i$ nadas bırakılmış, 167,225 (\%13,4)'i harir bahçesi ve 120,125 $(\% 9,6)^{\prime} i$ bağ olarak değerlendirilmişti. Hububat ekimi yapılmış 917 dönüm arazide $2.270(58.239,12 \mathrm{~kg})$ 'i buğday, 730 (16.242,5 kg)'u arpa ve $5(128,28 \mathrm{~kg})$ 'i burçak olmak üzere toplam 3.005 kile $(74.609,9 \mathrm{~kg})$ tahı üretimi gerçekleştirilmişti. Hane başına 10,04'ü hububat ve pamuk ekimi yapılmış, 0,3'ü nadasa bırakılmış, 1,79'u harir bahçesi ve $1,29^{\prime} u$ bağ olmak üzere toplam 13,42 dönüm arazi düşmekteydi. Hanelerden 91'i dört arazi türünden dönümleri değişmekle birlikte en az birine sahipti. Buna karşılık iki adet hanenin zirâat yapabilecekleri herhangi bir arazisi bulunmamaktaydı.

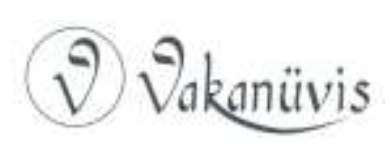


1844 'te Kasımlar Köyü'nde hayvansal varlık ise toplam 500 adetti ve hanelerden 73 (\%78,5)'ü en az bir hayvana sahipti. Bununla birlikte 20 adet $(\% 21,5)$ hanenin herhangi bir hayvanı bulunmamaktaydı. Hayvansal varlığın 180 (\%36)'i büyükbaş, 248 (\%49,6)'i küçükbaş ve 72 $(\% 14,4)$ 'si yük-binek grubuna girmekteydi. Hanelerden 65 'i büyükbaş, 3'ü küçükbaş ve 64'ü yük-binek hayvanlarına sahipti ve hane başına sırasıyla ortalama $2,76,82,66$ ve 1,12 olmak üzere toplam 86,54 baş hayvan düşmekteydi. Sağılan 158 adet büyük ve küçükbaş hayvandan toplam 21.705,5 L civarında süt üretilmişti. Bunun 14.911 L'si ineklerden, 5.671 L'si keçilerden ve 1.123,5 L'si de koyunlardan elde edilmişti. Hane başına senelik ineklerden 160,33 L, keçilerden $60,97 \mathrm{~L}$ ve koyunlardan $12,08 \mathrm{~L}$ olmak üzere toplam $233,38 \mathrm{~L}$ süt düşmekteydi.

Kasımlar Köyü'ndeki haneler kazançları karşılığında devlete öşür ve vergi-yi mahsusa adlarında iki tür vergi ödemişlerdi. Devlet hanelerden 1844 'te toplam 21.275,75 kuruş vergi toplamıştı; bu meblağın da $6.436,75^{\prime} i$ öşür ve $14.838^{\prime}$ 'u vergi-yi mahsusaydı. Bu vergi miktarı hane reislerinin 67.976,25 kuruşluk toplam kazançlarının oransal olarak \%31,3'üne tekabül etmekteydi. Hane başına ise 69,173'ü öşür ve 159,55’ü vergi-yi mahsusa olmak üzere toplam 228,723 kuruş vergi düşmüştü.

\section{Kaynakça}

Arşiv Kaynakları

- Başbakanlık Osmanlı Arşivi (BOA)

- Maliye Varidat Muhasebesi Temettuat Defterleri (ML. VRD. TMT. d.), nr. 8044.

Tezler

GÖKÇE, İsmail, 1844-45 Yılı Temettuat Sayımlarına Göre Sögüut ve Kırsalının Sosyal ve Ekonomik Yapısı, Eskişehir Osmangazi Üniversitesi Sosyal Bilimler Enstitüsü Basılmamış Yüksek Lisans Tezi, Eskişehir 2017.

TURĞUT, Vedat, Bilecik Bölgesi Örneğinde 16. Yüzyılda Vakıflar ve Şehirleşme, Sakarya Üniversitesi Sosyal Bilimler Enstitüsü Basılmamış Doktora Tezi, Sakarya 2011.

\section{(2) Vakaniwis}




\section{Sözlük, Kitap ve Makaleler}

ADIYEKE, Nuri, "Temettuat Sayımları ve Bu Sayımları Düzenleyen Nizamname Örnekleri", Ankara Üniversitesi Osmanlı Tarihi Araştırma ve Uygulama Merkezi Dergisi, 11, Ankara 2000, s. 769-825.

BARKAN, Ömer Lütfi, "Tarihî Demografi Araştırmaları ve Osmanlı Tarihi", Türkiyat Mecmuası, X, İstanbul 1953, s. 1-25.

Başbakanlık Osmanlı Arşivi Rehberi, Haz. Yusuf ìnsan Genç vd., Başbakanlık Devlet Arşivleri Genel Müdürlüğü Osmanlı Arşivi Daire Başkanlığı Yayınları, Ankara 2010.

BOZKURT, Nurgül, "1844-1845 Tarihli Temettüat Defterine Göre Kütahya Sancağı Dazkırı Kazası Evciler Köyü'nün Sosyal ve Ekonomik Yapısı", Uluslararası Sosyal Araştırmalar Dergisi, IV/19, (2011), s. 138-156.

EMECEN, Feridun, "Hudâvendigâr", Türkiye Diyanet Vakfı İslâm Ansiklopedisi, XVIII, s. 285-286.

GÖYÜNÇ, Nejat, "Hâne Deyimi Hakkında", istanbul Üniversitesi Edebiyat Fakültesi Tarih Dergisi, 32, İstanbul 1979, s. 331-348.

GÜRAN, Tevfik, "Osmanlı Tarım Ekonomisi, 1840-1910", 19. Yüzyılda Osmanlı Ekonomisi Üzerine Araştırmalar, Türkiye iş̧ Bankası Kültür Yayınları, İstanbul 2019.

GÜRAN, Tevfik, "19. Yüzyıl Temettüat Tahrirleri”, Osmanlı Devleti'nde Bilgi ve istatistik, Der. Halil İnalcık-Şevket Pamuk, Devlet İstatistik Enstitüsü Yayınları, Ankara 2000, s. 73-94.

HINZ, Walther, "islâm'da Ölçü Sistemleri", Marmara Üniversitesi Türklük Araştırmaları Dergisi, Çev. Acar Sevim, 5, ìstanbul 1989, s. 1-82.

KARPAT, Kemal H., Osmanlı Nüfusu 1830-1914, Timaş Yayınları, İstanbul 2010, s. 44-45.

KÜTÜKOĞLU, Mübahat S., "Osmanlı Sosyal ve İktisâdî Tarihi Kaynaklarından Temettü Defterleri", Belleten, LIX/238, Ankara 1999, s.395-412.

ÖZTÜRK, Said, Tanzimat Döneminde Bir Anadolu Şehri Bilecik, Kitabevi Yayınları, ìstanbul 1996.

ÖZTÜRK, Said, "Temettuat Tahrirleri", Akademik Araştırmalar Dergisi, 4-5, ìstanbul 2000, s.537-591.

PAKALIN, M. Zeki, "Temettü' Vergisi”, Osmanlı Tarih Deyimleri ve Terimleri Sözlüğü, III, Millî Eğitim Basımevi, İstanbul 1983, s. 453-455.

SAYIN, Abdurrahman Vefik, Tekâlif Kavaidi (Osmanlı Vergi Sistemi), Maliye Bakanlığı Araştırma, Planlama ve Koordinasyon Kurulu Başkanlığı Yayınları, II, Ankara 1999. 